\title{
Improved postoperative analgesia with preoperative piroxicam
}

J.J. O'Hanlon BSc MB FFARCSI, T. Muldoon MB FRCA, D. Lowry MB, G. McCleane MB FFARCSI
Purpose: Piroxicam like other Non-Steroidal Anti-Inflammatory drugs can be used to provide postoperative analgesia. With a half-life of $50 \mathrm{hr}$ given preoperatively its' analgesic effect should continue postoperatively. This study compared the effects of $20 \mathrm{mg}$ piroxicam given at different times in the perioperative period on postoperative analgesic requirement.

Method: Following ethical committee approval and written informed consent, 60 ASA I and II patients presenting for inpatient gynaecological laparoscopic surgery were given either $20 \mathrm{mg}$ piroxicam or a placebo po two hours preoperatively, immediately before induction of anaesthesia or one hour postoperatively in a randomised double bind manner.

Results: Postoperative Visual Analogue Pain Scores were lower on admission to the recovery ward in patients given piroxicam preoperatively (Group 1), than in the other two treatment groups (groups 2 and 3). Pain scores were $2.72 \mathrm{vs}$ 4.25 vs 6.67 respectively $(P<0.001)$. Pain scores did not differ at any other times. Time to first analgesic request was greater in the group I than in the other two treatment groups; 141 (61) min vs 115 (147) in Group 2 and 30 (36) $\mathrm{min}$ in Group 3. Nine patients in Group I requested further analgesia compared with 15 in Group 2 and 16 in Group 3. There were no piroxicam-induced side-effects.

Conclusion: Piroxicam given two hours preoperatively reduced pain scores, time to first analgesia and postoperative analgesic requirements compared with administration prior to induction or one hour postoperatively.

Objectif: Comme les autres anti-inflammatoires non stérö̈diens, le piroxicam peut être utilisé pour procurer l'analgésie postopératoire. Sa demi-vie étant de $50 \mathrm{~h}$, si on l'administre

\section{Key words}

ANALGESIA: postoperative;

ANALGESICS: NSAIDs, piroxicam;

SURGERY: laparoscopy.

From the Department of Anaesthetics, Craigavon Arca

Hospital, 68 Lurgan Road, Portadown BT63 5QQ.

Address correspondence to: Dr. J.J. O'Hanlon, Department of Clinical Anaesthesia, Royal Group of Hospitals, Grosvenor Road, Belfast, BT12 6BA.

Accepted for publication 15th October, 1995. avant l'intervention, son effet devrait se continuer en postopératoire. Cette étude a étudié les effets de $20 \mathrm{mg}$ de piroxicam administré à différents moments de la période périopératoire sur les besoins analgésiques postopératoires.

Méthode: Après approbation par le comité d'éthique et l'obtention d'un consentement éclairé, 60 patientes ASA I et II programmées pour une chirurgie gynécologique laparascopique ont reçu soit $20 \mathrm{mg}$ de piroxicam soit un placebo p.o. deur heures avant l'intervention, immédiatement avant l'induction de l'anesthésie ou une heure après l'intervention de façon randomisée et en double aveugle.

Résultats: A l'admission à la salle de réveil, les scores enregistrés sur une échelle visuelle analogue ont été plus bas chez les patientes qui avaient reçu le piroxicam avant l'intervention (Group 1) que dans les groupes 2 et 3. Les scores ont été respectivement de 2,72 vs 4,25 vs $6,67(<0,001)$. Aucune différence n'a été notée en aucun autre moment. Le délai avant la première requête pour un analgésique a été plus long dans le groupe I que dans les deux autres; 141 (61) min vs 115 (147) dans le groupe 2 et $30 \mathrm{~min}$ (36) dans le groupe 3. Neuf patientes du groupe I ont eu besoin d'un analgésique supplémentaire comparativement à 15 du groupe 2 et 16 du groupe 3. On n'a pas noté d'effets secondaires attribuables au piroxicam.

Conclusion: Le piroxicam administré deux heures avant l'intervention diminue les scores de douleur, prolonge le délai avant le premier analgésique et diminue le besoin postopératoire d'analgésique comparativement à son administration à l'induction et une heure après l'intervention.

Postoperative analgesia comparable with that of opioids has been demonstrated with the non-steroidal antiinflammatory drugs (NSAIDS). ${ }^{1.2}$ An opioid sparing effect has also been observed with NSAIDS, as well as a reduction in opioid induced nausea, vomiting and respiratory depression. This reduction in opioid requirement and side-effects may benefit the patient by producing increased postoperative analgesia and, even, reduce hospital stay. ${ }^{3}$

By inhibiting the enzyme cyclo-oxygenase and preventing the central and peripheral synthesis of prostaglandins, ${ }^{4}$ NSAIDs reduce the inflammatory component of pain generation. Prostaglandins are released 
from damaged tissue and directly sensitise peripheral nociceptors, and they also play a role in primary and secondary hyperalgesia. ${ }^{5}$

Analgesics given before surgical trauma are thought to have a pre-emptive effect; implying that analgesia will start before the surgical stimulus, leading to a reduction of CNS input and, hence, reducing pain. ${ }^{6.7}$ Studies using different NSAIDs pre-emptively have had mixed results; some studies showing a benefit others showing no benefit. ${ }^{8.9}$

In this study we investigated the postoperative analgesic effect of piroxicam given at different times in the perioperative period. The "melt" formulation of piroxicam was used. In the "melt" tablet the drug is freezedried and, on contact with saliva, the tablet dissolves and the drug is swallowed and absorbed from the gastrointestinal tract; there is no sublinguial absorption. Thus the use of the "melt" tablets avoids patients having to swallow tablets or suffer im injections. ${ }^{10}$

\section{Methods}

The protocol was approved by the Regional Ethics Committee. Following informed written consent 60 ASA 1-2 patients presenting for diagnostic laparoscopy received, in a double blind manner, either $20 \mathrm{mg}$ piroxicam or placebo in the "melt" form at the following times; two hours preoperatively, immediately before induction of anaesthesia or one hour postoperatively.

Patients with known hypersensitivity to NSAIDs, peptic ulcer disease, asthma, renal impairment or receiving concurrent NSAID medication were excluded from the study.

Each patient was premedicated with the benzodiazepine temazepam $10-30 \mathrm{mg}$ po. Anaesthesia was induced with propofol $2 \mathrm{mg} \cdot \mathrm{kg}^{-1}$ and fentanyl 1 $\mathrm{mg} \cdot \mathrm{kg}^{-1}$ iv and tracheal intubation was facilitated with atracurium $0.5 \mathrm{mg} \cdot \mathrm{kg}^{-1}$. Anaesthesia was maintained with isoflurane $1-1.2 \%$ (inspired concentration) in nitrous oxide $65 \%$ in oxygen. On completion of the procedure muscle relaxation was reversed with $2.5 \mathrm{mg}$ neostigmine and $0.5 \mathrm{mg}$ glycopyrrolate.

The patients' age, height and weight were recorded. Time to the patients' first spontaneous request for analgesia was noted. Postoperative pain was assessed by asking the patient to complete a $10 \mathrm{~cm}$ visual analoguc scale (VAS): $0=$ no pain and $10=$ worst pain, at the following times after surgery; on admission to the recovery ward, and at one, two, four, eight, and twenty-four hours. The $10 \mathrm{~cm}$ Visual Analogue Score had been explained to the patient at the preoperative visit.

Postoperative analgesia was provided by either cyclimorph ' 10 ' $0.1 \mathrm{ml} \cdot \mathrm{kg}^{-1}$ or co-codamol (paracetamol $500 \mathrm{mg}$ and codeine $8 \mathrm{mg}$ ), two tablets, and this
TABLE I Physical characteristics in the treatment groups. Valucs are mean (SD).

\begin{tabular}{lccc}
\hline & $\begin{array}{c}\text { Group I } \\
(n=20)\end{array}$ & $\begin{array}{c}\text { Group 2 } \\
(n=20)\end{array}$ & $\begin{array}{c}\text { Group 3 } \\
(n=20)\end{array}$ \\
\hline Age: $(y r)$ & $31(10.6)$ & $29(5.5)$ & $29(7.3)$ \\
Height: $\mathrm{cm}$ & $161(11.2)$ & $164(10.7)$ & $162(7.5)$ \\
Weight: $\mathrm{kg}$ & $61.5(10.3)$ & $64(11.4)$ & $69(12.2)$ \\
\hline
\end{tabular}

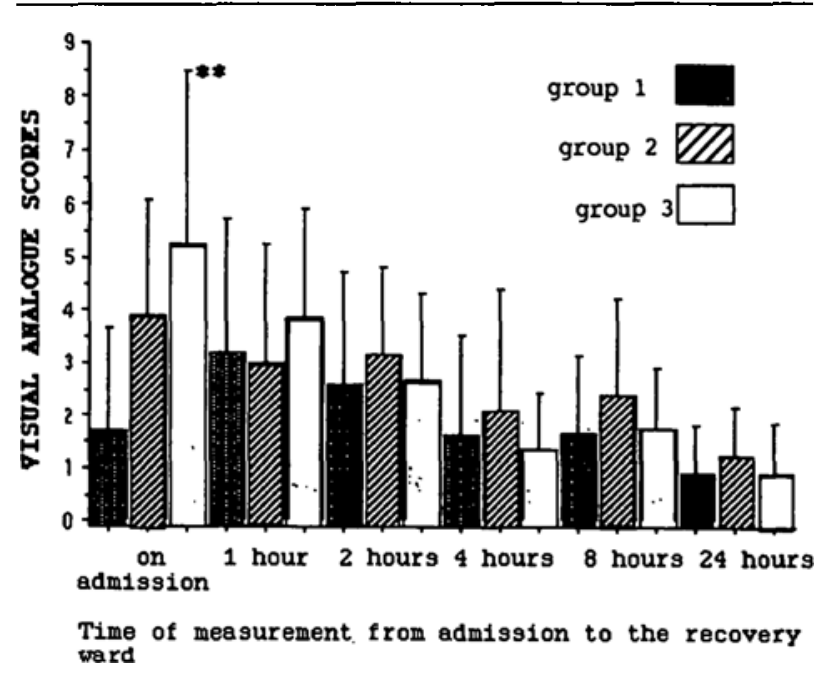

FIGURE Visual analoguc scores belween the different groups, $P<$ 0.05 .

was given to the patient as soon as analgesia was requested.

Statistical analysis was carried out using Analysis of Variance for continuous data. The Kruskall-Wallis test was used for non-parametric data. The difference between groups was tested using Chi-Squared tests.

\section{Results}

Patients in the three treatment groups were equally matched with respect to age, height and weight (Table I).

Pain scores recorded on admission to the recovery ward differed. Patients receiving piroxicam two hours preoperatively (Group 1) had lower scores than Group 2 (induction group) or Group 3 (postoperative group) $(P<$ $0.0004)$. There was no difference in the scores at any other times (Figure).

Time to first analgesia differed among the three groups (Table II) $P<0.05$.

Postoperative analgesic requirements also differed. In Group I patients nine patients of 20 required further analgesia postoperatively, compared with 16 in Group 2 and 15 in Group $3(P<0.04)$ (Table III). In Group 1 only four patients required morphine as the postopera- 
TABLE II Time to first analgesia in the three treatment groups. Values are mean (SD).

\begin{tabular}{lllll}
\hline & $\begin{array}{c}\text { Group }) \\
(n=20)\end{array}$ & $\begin{array}{c}\text { Group 2 } \\
(n=20)\end{array}$ & $\begin{array}{l}\text { Group 3 } \\
(n=20)\end{array}$ & $P$ \\
\hline $\begin{array}{l}\text { Time to first analgesia } \\
(\min )\end{array}$ & $141(185)$ & $115(148)$ & $30(36)$ & $<0.032$ \\
\hline
\end{tabular}

TABLE III Number of patients requesting further analgesia in the three treatment groups and the type of analgesia required.

\begin{tabular}{llll}
\hline & $\begin{array}{c}\text { Group }) \\
(n=20)\end{array}$ & $\begin{array}{c}\text { Group 2 } \\
(n=20)\end{array}$ & $\begin{array}{l}\text { Group 3 } \\
(n=20)\end{array}$ \\
\hline Number of patients requesting & & & \\
- Further analgesia & 9 & 15 & 16 \\
- Cyclimorph & 4 & 13 & 15 \\
- Paracetamol/codeine & 5 & 2 & 1 \\
\hline
\end{tabular}

tive analgesic, compared to 13 in Group 2 and 15 in Group 3 (Table III).

There was no evidence of NSAID-induced sideeffects.

\section{Discussion}

Analgesia given immediately before surgical stimulus has been described as "pre-emptive" analgesia." Preemptive analgesia prevents or reduces central hyperexcitability, leading to improved postoperative analgesia and reduced postoperative analgesic requirement. Studies using preoperative opioids, local anaesthetics or NSAIDs have shown mixed results. Tverskoy demonstrated the advantage of preincisional wound infiltration in inguinal hernia repair" but subsequent studies comparing pre and post-incisional local anaesthetic blocks has not shown a distinct advantage of preoperative local anaesthesia. ${ }^{12}$

Recent studies using opioids have shown that alfentanil was ineffective pre-emptively. ${ }^{13}$ However, Richmond et al. ${ }^{14}$ demonstrated that preoperative morphine reduced pain scores and postoperative analgesic requirement in patients undergoing abdominal hysterectomy. Morphine has a longer duration of action than alfentanil, suggesting that shorter acting analgesics do not have a sufficiently long time of action to provide pre-emptive analgesia. Preoperative treatment may only have a short pre-emptive effect and so not be clinically relevant. ${ }^{6}$ Piroxicam with its long half-life and when given preoperatively may provide a longer effect that is clinically relevant.

Instrumentation of the uterus and Fallopian tubes during laparoscopy or surgery leads to prostaglandin release and, the prostaglandins released play a role in pain following laparoscopy. ${ }^{15}$ Inhibition of prosta- glandin production by the NSAIDS both peripherally and centrally should, therefore, decrease postoperative discomfort and reduce opioid requirement. ${ }^{2,4}$ Similarly NSAIDS are used to good effect in the treatment of dysmenorrhea. ${ }^{16}$

Preoperative naproxen and piroxicam demonstrated superior analgesia to placebo, for patients undergoing laparoscopic surgery. ${ }^{17.18}$ However, to demonstrate a pre-emptive effect, preoperative treatments must be compared with postoperative. Preoperative diclofenac showed no difference from postoperative diclofenac in patients undergoing laparoscopic lubal ligation ${ }^{7}$ and similar results were seen with ketorolac and ibuprofen. ${ }^{19,20}$ Preoperative indomethacin demonstrated no advantage in patients undergoing thoracotomy. ${ }^{21}$ Bradford et al., however, showed that a combination of ketorolac and bupivacaine applied to the fallopian tubes and infiltrated to the trochar sites reduced both pain and nausea following laparoscopic surgery, ${ }^{22}$ suggesting that a single analgesic treatment is ineffective in providing adequate analgesia for painful procedures.

However, preoperative administration of ketorolac, piroxicam and diclofenac did reduce postoperative pain in patients undergoing laparoscopy. ${ }^{8,23}$ In our study the patients given piroxicam two hours preoperatively requested less analgesia and had a longer time to first analgesic request than patients given piroxicam prior to induction or postoperatively. In Group 1 only four patients required a postoperative opioid compared with 13 in Group 2 and 15 in Group 3, this analgesic requirement may explain why the pain scores only differed on admission to the recovery ward. Patients in Group 1 had very low VAS scores 2.72 on admission to recovery ward compared with other NSAID studies. ${ }^{7.20}$ The studies using pre and postoperative ketorolac or diclofenac used patients undergoing laparoscopic tubal ligation which may explain the higher pain scores than patients in Group 1. Although none of our patients underwent sterilization, the pain scores in Groups 2 and 3 were similar to those in previous studies. Patients in Group 1 received $20 \mathrm{mg}$ piroxicam preoperatively, which is the probable reason for the reduction in pain scores. However it is difficult to compare the analgesic efficacy of the NSAIDS, ${ }^{24}$ between studies and so a direct comparison of other NSAIDS with piroxicam would be necessary.

Piroxicam given two hours before laparoscopic surgical procedures, excluding tubal ligation, had an analgesic effect. Its use resulted in lower pain scores and less analgesic requirement than pre-induction or postoperative administration. Patients in Groups 2 and 3 required more postoperative analgesia and so piroxicam, when given preoperatively, continued to have an effect 
in the postoperative period. The advantage of this is that with a long half-life, ${ }^{24}$ only a single daily dose is required. Therefore we conclude that piroxicam given preoperatively in the "melt" form is a useful analgesic for intermediate surgical procedures.

\section{References}

1 Gillies GWA, Kenny GNC, Bullingham RES, McArdle CS. The morphine sparing effects of ketorolac tromethamine. A study of new, parenteral non-steroidal anti-inflammatory agent after abdominal surgery. Anaesthesia 1987; 42: 727-31.

2 Rosenblum M, Weller RS, Conrad PL, Falvey EA, Gross $J B$. Ibuprofen produces longer lasting analgesia than fentanyl after laparoscopic surgery. Anesth Analg 1991; 73: 255-9.

3 Gold BS, Kitz DS, Lecky JH, Neuhaus JM. Unanticipated admission to the hospital following ambulatory sugery. JAMA 1989; 262: 3008-10.

4 McCormack $K$. Non-steroidal anti-inflammatory drugs and spinal nociceptive processing. Pain 1994; 59: 9-43.

5 Dahl $J B$, Kehlet $H$. Non-Steroidal anti-inflammatory drugs: rationale for use in severe postoperative pain. $\mathrm{Br} \mathrm{J}$ Anaesth 1991; 66: 703-12.

6 McQuay HJ. Pre-emptive analgesia: a systematic review of clinical studies. Ann Med 1995; 27: 249-56.

7 Woolf CJ, Chong M-S. Preemprive analgesia - treating postoperative pain by preventing the establishment of central sensitization. Anesth Analg 1993; 77: 362-79.

8 Buggy DJ, Wall C, Carton EG. Preoperative or postoperative diclofenac for laparoscopic tubal ligation. $\mathrm{Br} \mathrm{J}$ Anaesth 1994; 73: 767-70.

9 Gillberg LE, Harsten AS, Stahl LB. Preoperative diclofenac sodium reduces post-laparoscopy pain. Can J Anaesth 1993; 40: 406-8.

10 Power I. Muscle damage with diclofenac injections (Letter). Anaesthesia 1992; 47: 451.

11 Tverskoy M, Cozacov C, Ayache M, Bradley EL Jr, Kissin l. Posloperative pain after inguinal herniorrhaphy with different types of anesthesia. Anesth Analg 1990; 70: 29-35.

12 Ejlersen $E$, Andersen $H B$, Eliasen $K$, Mogensen $T$. A comparison between preincisional and postincisional lidocaine infiltration and postoperative pain. Anesth Analg 1992; 74: 495-8.

13 Mansfield $M$, Miekle $R$, Miller $C$. A trial of pre-cmptive analgesia. Influence of timing peroperative alfentanil on postoperative pain and analgesic requirements. Anacsthesia 1994; 49: 1091-3.

14 Richmond CE, Bromley LM, Woolf CJ. Preoperative morphine pre-empts postoperative pain. Lancet 1993; 342: 73-5.

15 Wang $Z, W u R, G e X$, et al. Relationships between pelvic pain and prostaglandin levels in plasma and peritoneal fluid collected from women after sterilization.

Contraception 1992; 45: 67-71.

16 Dawood MY. Ibuprofen and dysmenorrhea. Am J Med 1984; 77: 87-94.

17 Comfort VK, Code WE, Rooney ME, Yip RW. Naproxen premedication reduces postoperative tubal ligation pain. Can J Anaesth 1992; 39: 349-52.

18 Serpell MG, Thompson MF. Comparison of piroxicam with placebo in the management of pain after total hip replacement. Br J Anaesth 1989; 63: 354-6.

19 Shapiro $M H$, Duffy $B L$. Intramuscular ketorolac for postoperative analgesia following laparoscopic sterilisation. Anaesth Intensive Carc 1994; 22: 22-4.

20 Higgins MS, Givogre $J L$, Marco AP, Blumenthal PD, Furman WR. Recovery from outpatient laparoscopic tubal ligation is not improved by preoperative administration of ketorolac or ibuprofen. Anesth Analg 1994; 79: 274-80.

21 Murphy $D F$, Medley $C$. Preoperative indomethacin for pain relief after thoracotomy: comparison with postoperative indomethacin. Br J Anaesth 1993; 70: 298-300.

22 Bradford TH, Robertson K, Norman PF, Meeks GR. Reduction of pain and nausea after laparoscopic sterilization with bupivacaine, metoclopramide, scopolamine, ketorolac, and gastric suctioning. Obstet Gynccol 1995; 85: 687-91.

23 Lysak SZ, Anderson PT, Carithers RA, DeVane GG, Smith $M L$, Bates $G W$. Postoperative effects of fentanyl, ketorolac, and piroxicam as analgesics for outpatient laparoscopic procedures. Obstet Gynecol 1994; 83: 270-5.

24 McCormack $K$, Brune $K$. Dissociation between the antinociceptive and anti-inflammatory effects of the nonsteroidal anti-inflammatory drugs. Drugs 1991; 41: 533-47.

25 Calin A. Therapeutic focus. Piroxicam. Brit J Clin Prac. 1988; 42: 161-4. 